\title{
Role of Advanced Farmers in Agriculture and Rural Development in the Mekong Delta, Vietnam
}

\author{
Nguyen Ngoc De* and Kotaro Ohara**
}

\section{ベトナムメコンデルタにおける農業・農村発展に及ぼす先進的農業者の役割}

\author{
グエン・ゴク・デ（カントー大学・ベトナム） \\ 大 原 興太郎（三重大学生物資源学部）
}

本論文はメコンデルタにおける農業農村発展に及ぼ す先進的農業者の歴史的役割を分析するものである.

異なった農業生態的条件の下で, メコンデルタの農民 は試行錯誤によって, よりよい農業生産をあげるため に彼らの農地の諸問題を克服するための土壤・水利・作 物管理についてのさまざまな技術を創出してきた。

このような試行錯誤から学ぶことによって, 農民, と りわけ先進的農民は先ず特定の条件に適う作物や品種 を選択し, 栽培暦を調整し, 上地・水管理の方法を変 え, そして地域資源の最適な利用に相応しい耕作法に 変えてきた.

彼らは自分たちでそれらを工夫するだけではなく, 試 験研究機関や普及活動などの外部からのあたらしい技 術を試みてみるリスクも引き受けている. 彼らの知識
は自身の経験のみでなく他の人々との相互作用からも 創られている，彼らの実際的な知識は農業・農村発展 過程に対してもたいへん貴重なものである.

先進的農民たちは地方レベルにおける技術移転にお いても重要な役割を果たしている。彼らは科学者と農 村集落との架け橋にもなっている. それ以上に, 多く の文献は，隣の農民からもたらされる情報がしばしば 外部者から供給される情報よりもしばしばより重要で 信頼度の高いものであることを示している．したがっ て，農業普及ネットワークは先進的農業者を積極的な パートナーとみなし, 彼らを効果的な技術発展を動機 づける農村協力者として組み込むことがもっと考えら れるべきである。

\section{Introduction}

The development of agriculture in the Mekong Delta since Vietnam's unification (1975) is usually credited for the improvement of irrigation systems, the introduction of modern varieties, the dissemination of advanced technologies in farming and the change in agricultural and land use policies (Xuan, 1993). However, there is no doubt that farmers, especially advanced farmers, are

\footnotetext{
* Mekong Delta Farming Systems Research and Development Institute, Can Tho University, Vietnam

** Professor of Farm Management and Sociology, Faculty of Bioresources, Mie University, Japan
}

the key players in this dramatic development.

In the whole process of agricultural and rural development in developing countries, the contribution of farmers, in general, and advanced farmers, in particular, is very important. They have been the local technology developers, adapters, motivators, and so on. Experience from Japan during the initial growth phase of economic development (Meiji Era) showed that the so-called "Rõnô" farmers (veteran farmers) had been very active and played an important role in improving and disseminating the local varieties, seeds, and cultivation techniques to increase agricultural productivity (Hayami, 1975). Vietnam is not an exception. 
Even with the unavailability of research and extension during the traditional farming period, the limitation of research and extension during the war time and the absence of agricultural extension works and centrally planned economy during the collectivization period, farmers continued to develop various kinds of technologies and appropriate land use systems and greatly contributed to agricultural growth and rural development in the Mekong Delta. The question is, "Who led the agricultural development during such difficult environmental and socio-political conditions at the local level?" It is hypothesized that the leading farmers who are advanced in technological knowledge, experience and skills may take the leadership role in various ways. What functions did they play and how can their roles be promoted?

This paper analyzes the role and function of advanced farmers in agriculture and rural development in the Mekong Delta. The paper focuses on how to better use the roles and functions of advanced farmers to speed up the economic development process and draw special attention of policy makers, authorities and scientists to improve the effectiveness of agricultural extension works in the Delta at present and in the future.

\section{Advanced farmers and agricultural devel- opment}

\section{(1) Agricultural development in the Mekong Delta and farmers}

The Mekong Delta plays the most important role in Vietnamese agriculture. With $12 \%$ of the natural land and $31.6 \%$ of the agricultural land, the Mekong Delta accounts annually for $51.4 \%$ of rice production, $70 \%$ of fruit production, and $80 \%$ of fish production for the whole country. Rice is the most important crop in the Mekong Delta. The agricultural development since the unification of the country (1975) can be divided into 2 phases: collectivization period (1975-1981) and under renovation period (1981 to date).

One year after unification, the Mekong Delta had moved gradually towards collectivization. In 1980, most rice areas were collectivized and farmers were orga- nized into production groups. Land was re-distributed based on the number of people in each family with no long-term tenure security. Farmers were considered simply as agricultural workers who turned commands and instructions from planners and local administrators into practice without any questions. As a result food output sharply declined. Locally technological potential and indigenous knowledge were neglected in the Mekong Delta unlike in Japan where during the initial stage of agricultural development, indigenous technological potential was effectively utilized before the modern technological potentials were made available to farmers (Hayami, 1975). The Mekong Delta situation was also very different from the other developing countries such as the Philippines, Thailand, and Bangladesh at the comparable time period due to different political structures and institutions. Southern agriculture continued on a family farm basis despite collectivization. Up to 1986 , only $5.9 \%$ of farmers in the Mekong Delta were members of low rank cooperatives, compared to $99.4 \%$ in the Red River Delta. Farmers continued to be the primary decision makers for all input and technology decisions on their assigned land. Sharing of labor became especially important among farmers in the community for power intensive operations such as land preparation and harvesting (Pingali, 1990). In such conditions, some knowledgeable and skillful farmers in farming technology and community organization took a leadership role.

In 1981 there was a switch from a fixed wage to a fixed rent system of production under the introduction of the contract system. The fixed rent system was reenforced by a series of reform policies (known as "Doi $M o i$ " or renovation in 1988) in land allocation, tenure security, privatization of input and output markets and other related issues to the market-oriented economy. As a result, food output started to level off between 1981 and 1987 (annual growth rate 2.8\% compared to $1.9 \%$ for 1976-81) (Xuan, 1997), and rise up during the period of 1990 to date at average annual growth rates of $3.0-4.0 \%$. Extension works had been independently carried out by the officers from various Ministries (Agriculture, Fisheries, Forestry, Water resource 
management, etc.), through their line departments at provincial level. Research institutions, agricultural universities and chemical companies were also involved. These unorganized and uncoordinated activities clearly resulted in unnecessary duplication of efforts, wasteful expenditures, and ineffective technology promotion because of the top-down approach in technology transfer was still prevailing. In this system there was little opportunity left for the farming households to learn more about the resource system they possessed and then select the farming system that was more appropriate for them (Xuan, et al., 1993). Again, those farmers who were more experienced, skillful and knowledgeable emerged to be a symbolic model for other farmers in their communities to follow.

Since the establishment of the National Agricultural Extension system in March 1993, the applied research and diffusion of modern technologies have been speeded up, and advanced farmers have been encouraged to take the lead in the process of technological and community development. However, unlike in Japan where Rõnõ or veteran farmers were mobilized to travel around the country to demonstrate and train other farmers on their technological potentials, the impact of advanced farmers in the Mekong Delta were limited within their local areas.

\section{(2) Characteristics of advanced farmers}

There are many terms used by various authors and institutions to express the similar concept of advanced farmers. Some major concepts have been adapted in Vietnam agriculture as follows:

The concept of "outstanding farmers" generated by IRRI (IRRI, 1985) is mainly based on the result of works, which are more productive than the others among good farmers in his/her societies. With this concept, the leading role and creditability of farmers in their local communities were not carefully evaluated.

Subedi et al. (2001) referred to the farmers who play the key role in community seed supply and exchange networks as "Nodal farmers". This concept seems to be based on the role of farmers in transferring and disseminating information and new seeds in their communities.
The Agricultural Extension Center of Tien Giang province (1997) set 4 qualification criteria for "progressive farmer" recognition at the village, district and provincial levels. They are required (1) to be a good citizen, (2) to guide and help other farmers in agricultural development with high creditability to local farmers, (3) to be an active member of local farmers' association ${ }^{1)}$ and agricultural extension club $^{2)}$ and (4) to be hard working on the farm, be open to knowledge advancement, have good adoption of new technologies and have high profitability in agricultural production. The latter criterion is used to classify farmers at the village, district or provincial level for recognition of progressive farmers if their annual family incomes reach 20,30 or 40 million VND and above, respectively. However, the practical classification is mainly based on economic consideration.

Similarly, in the initial growth phase of Japanese agriculture those among the gono (landlords who personally farmed part of their land holdings) who were especially experienced and skillful in farming were called "rõnõ" or veteran farmers (Hayami, 1975).

In the general Vietnamese context, the advanced farmers are not only, and sometimes not necessarily, outstanding ones. In this paper, we consider the advanced farmers in a broader meaning in value of both works and spirits of performance. The characteristics of advanced farmers in the Mekong Delta can be described as follows:

Value of works: (1) Good experiences, knowledge and skills in farming and (2) Good work achievement

Spirit of performance: (1) Pioneer to try new things, sometimes right, sometimes wrong, but they are the ones who are not satisfied with the current situation and always think it should be better and work on that, (2) Good contribution to community development and (3) High social credibility.

\section{(3) Emergence of advanced farmers in the Mekong Delta}

The three important elements that make the ordinary farmer become the advanced farmer are knowledge, skill accumulation and social prestige or credibility. Farmers' experiences and skills are accumulating from 
doing by themselves, while knowledge comes from observation or interacting with their neighbours, researchers, extension workers, written literatures (newspapers, magazines, books,), public multimedia (radio, TV, loudspeakers) and also transferring ancestral (indigenous) knowledge (Figure 1).

To emerge as advanced farmers in the area, beside the technical recognition (experiences, skill and knowledge), the socio-economic and cultural factors are also required (under needed conditions for improving and changing the current farming practices in the community). They also must have good social behaviour and personal attitude to gain good a reputation and credibility or prestige in their communities. Aged people are also respected in Vietnamese tradition and custom.

For Mekong Delta farmers, the indigenous knowledge and experiences were most important for guiding their works during the periods before the reunification in 1975 due to the poor information facilities, research and extension systems during the war time. After 1975 , farmers have more access to information through many ways of communication. Their knowledge has been built up mainly from public multimedia (radio and TV) and research and extension networks. The advanced farmers in the area gain more advantage than

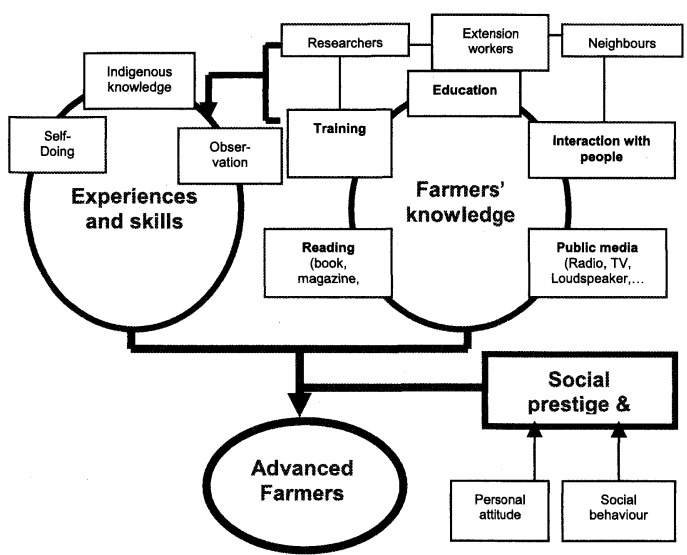

Figure 1. Diagram showing the factors influencing the emergence of advanced farmers

Arrows show the flow of accumulation process of farmers' knowledge, experience and skill through various sources of information. the common ones due to their active attitude of eagerness to try something new. A relatively high educational level is also an advantage of advanced farmers so they can better absorb, analyze and make use of information from training, reading or observation. Government policies also have a strong impact on personal knowledge accumulation and the role of advanced farmers. Close linkage with extension work and favorable government policies stimulate these processes.

\section{Roles and functions of advanced farmers: A case study}

\section{(1) Advanced farmers as technical innovators} for local adaptation of new technologies:

1) Improvement of local biodiversity

Farmers, especially advanced farmers, have played a very important role in conserving and developing local genetic resources for crop improvement. For generations, farmers have looked for and developed crop species and varieties that are suitable for certain conditions. Many local traditional rice cultivars, closely related to the farmers' names indicating those who had selected them or reflected their daily life, have been grown widely in the Mekong Delta for a long time when irrigation was poorly developed. Some examples are:

In the flooded condition, to deal with the very deep level (up to $3 \mathrm{~m}$ ) and fast increase of flooding water in the rainy season, floating rices, which have elongating ability to keep their leaves and panicles above the water surface and are ready to harvest by the end of flooding period, were developed by farmers in such ecosystem.

In the deep-water condition (maximum water depth from $0.5-1.0 \mathrm{~m}$ ), hundreds of local traditional rice cultivars with tall culms, large panicles, strong photoperiod sensitivity and late maturity have been selected by farmers to stand in such conditions. The most common one is the Tai Nguyen rice variety which was selected by a farmer known as Mr. Nguyen Tai Nguyen in Long My District, Can Tho Province in the 1970s. (N.N. De, 1996). 
In the rain-fed saline condition, local farmers have selected appropriate maturity cultivars to fit the strictly limited growing season. These cultivars were planted when the rain water was available in the field and ripened when the field dried up at the end of the rainy season.

Even in the irrigated area, where modern rice varieties had been introduced by research institutions no more than 35 years ago, further improvements by farmers of introduced breeding materials for their specific environments have been observed. These efforts enrich biodiversity for local use.

2) Testing and modification of introduced technologies for local adaptation

The new technologies are mainly from research institutions, universities and extension networks. Advanced farmers are the first ones to try, experience and modify new technologies and practices according to their local specific conditions and under their preferences. They agree to take risks in trying something new before the others and become a good example for other farmers in the area to learn from.

The MTL58 rice variety released by Can Tho University in 1982 is a good example. It has resistance to Brown Plant Hopper (a major rice insect pest in the Mekong Delta) and high yields but also has poor grain quality and is susceptible to leaf blast disease. Mr. Hai Huu (Long An Province), who has cultivated 1 ha of paddy in the acid sulphate and saline soil area since 1975, created the new strain of MTL58 for acid sulphate soil tolerance and better grain quality with less chalkiness in the grain kernel. This improved variety was then spread out to $70-80 \%$ of the rice cultivated land in the province with more than 10 years of production. About the same time, Mr. Ba Cung (An Giang Province), who before 1975 was a former primary school teacher, picked up and multiplied one individual healthy plant of MTL58 left on the rice blast resistant nursery test on his field. Its resistance ability to rice blast disease was confirmed by scientific tests. The reselected variety was adopted in his community and expanded in large-scale production in An Giang Province and some other provinces under rice blast disease pressure. Similarly, Mr. Hai Triem (An Giang Province) and Mr. Nam Chau (Tra Vinh Province) are representatives for further improvement of institutions' rice varieties for good grain quality by pureline selection because of high market demand for better grain quality. Mr. Hai Chung and Mr. Ba Chuong in Tien Giang Province are typical farmers for integrating' traditional and new farming technologies. They have used animal manure and incorporated rice straw for soil fertility restoration in their intensive rice cropping fields with three crops per year for more than 30 years. Each of them always keeps a part of his land for testing new varieties or new methods of cultivation in every season for pre-evaluation and location-specific adaptation.

As an example of farmers' modification of introduced technologies, a survey was conducted in 2003 in six selected villages of An Giang, Can Tho, and Tra Vinh Provinces on the impact of the drum seeder and

Table 1. Comparison of IRRI-style and modified Vietnamese style drum seeders

\begin{tabular}{|c|c|c|c|}
\hline Items & $\begin{array}{l}\text { Origin IRRI-style } \\
\text { drum seeder }\end{array}$ & $\begin{array}{l}\text { Modified Vietnamese style } \\
\text { drum seeder }\end{array}$ & Results \\
\hline Material & Steel & Plastic & Easy to produce with local enterprises \\
\hline Weight & Heavy ( $>12 \mathrm{~kg}$ ) & Light $(6 \mathrm{~kg})$ & Easy to carry even by women \\
\hline Cost & High $(500,000$ VND) & Reasonable $(300,000 \mathrm{VND})$ & Farmers can afford to buy \\
\hline Transport & Difficult, heavy, clumsy & Easy to break into small parts & More convenient \\
\hline $\begin{array}{l}\text { Holes for seed } \\
\text { drop }\end{array}$ & Small & Large enough & Suitable for Vietnamese rice seed size \\
\hline Color & Yellow-red & Light blue & Farmers prefer blue color while work under the sun \\
\hline
\end{tabular}

Field data, 2003, Abedin, Z.M., T. Paris and N.N. De (2004). 
modern varieties on rice production. With a total of 138 respondents participating in focus group discussions, the results showed that the major advantages of the drum seeder were reducing seed rates from 200 to 80 $120 \mathrm{~kg} / \mathrm{ha}$, thus, reducing the cost of seeds; easier weed control due to sowing in lines; less pest incidence and higher profitability. The IRRI-style drum seeder (row sowing) has been introduced to the Mekong Delta since 1996. But the fast adoption was made recently when farmers modified and finally replaced the original steel-made heavy and clumsy drum seeder with the local tin-made lighter, drum seeder and further by the plastic portable drum seeder (Table 1).

3) Development of location-specific technologies

Farmers are not only adapting new technologies from outside sources but also are very active in trying new things by themselves for better use of their local resources to feed their families. Farmers are the pioneers who identify and fight against the problems in agricultural production because they are directly depending on the land for their living.

The history of agricultural development in the Mekong Delta has definitely proved their important role. They, by trial and error, adjusted cropping patterns and seasonal calendars to avoid and reduce the risks of crop losses; selected suitable crops and varieties for different soil types (acidity, salinity) and flooding conditions; and improved soil and water management and cultural practices to increase crop productivity.

Many researchers have provided supporting evidence. Xuan et al. (1982) are the first to describe two cultivation techniques developed by farmers on acid sulphate soil. The first technique is the shallow drainage system which speeds up the removal of soluble toxins in the early rainy season and second is the "acid avoidance technique", a system whereby rice is planted at the end of flood season. Xuan et al. (1991) also report the use of Melaleuca leucodendron for forestry in extremely strong acid sulphate soil where no crop could survive. They also illustrate the use of the "zero-tillage technique" for growing rice to shorten the transition period between two succeeding crops, to save limited available water for land preparation and to avoid being damage by acidity at the early stage of the early rainy season crop. Nga et al. (1996) describe the way farmers grow pineapples and sugarcane. Tri (1996) reviews the farmers' practices for cassava, yam, sweet potato, and jute cultivation in acid sulphate soils using raised-bed systems to increase the root zone and reduce the negative effect of acidity.

These successful practices were derived from their self-learning by "trial and error" for several years when research and extension were still untouched.

\section{(2) Advanced farmers as local technicians ${ }^{3)}$}

Under an FAO-funded IPM (Integrated Pest Management) program since 1992, thousands of advanced farmers were trained to become local IPM trainers for other farmers. The project has lasted almost ten years and a hundred thousand farmers have been trained. At the village level, a group of 5-6 farmer trainers was formed and they themselves organized the training courses for local farmers using "Farmer Field School" $(\mathrm{FFS})^{4)}$ approaches or "Farmers Participatory Research" $(\mathrm{FPR})^{5)}$.

These approaches were then followed by DANIDA ${ }^{6)}$ post harvest project in some provinces like Can Tho, Soc Trang.

FFS approaches have been used under the Community Biodiversity Development and Conservation $(\mathrm{CBDC})^{7)}$ project to implement the Participatory Plant Breeding and Participatory Varietal Selection (PPB/ PVS) ${ }^{8)}$ in the Mekong Delta since 1994. With five communities at the beginning, the project has now effectively expanded to 38 communities with more than 1000 participating farmers in all 13 provinces of Mekong Delta. The project has trained many farmers to be the local trainers for project expansion. Another project, the "Strengthening the Scientific basis of Agricultural biodiversity conservation-on farm" International project coordinated by IPGRI (Plant Genetic Resource Institute) was implemented in 1998 in 7 agro-ecosystems of Vietnam. It has also confirmed the important roles of local farmers, especially advanced farmers, regarding their local genetic resources. Lessons learned from these projects reveal that the 
participatory approach in technological diffusion is very effective. Learning by doing and farmer-to-farmer training are especially important. Using local people who have demonstrated their good ability by actual works and well understand the physical and sociocultural situations as trainers is more convincible and reliable to local farmers than outsiders.

\section{(3) Advanced farmers as community motivators for agricultural and rural development}

Advanced farmers are not only the technical innovators and local technicians but also community development leaders. They are not only trying and doing good things for themselves but also for the benefit of their communities. They share their good seeds, knowledge, skills and experiences with their neighbours through facilitating the demonstration plots and group discussion of new technologies, conducting the technical trainings, field coaching and daily communication. Through history, strong ties between villagers have been maintained within each communal area. These ties have generated various forms of farmers' associations or farmer groups that formed when necessary to share information, to control and manage land and water resources as the municipal unit (Cho, 2001). Moreover, within the community, they are all related as relatives or long time friends since their childhoods and often have contact in several social activities. In many cases, sharing experiences takes place easily.

As an aged and respectful person and experienced and skillful farmers in the community, Mr. Hai Huu is the founder and leader of local seed production group of the village of My Phu, Thu Thua District (Long An Province). Under Mr. Hai Huu's leadership, the group selects suitable varieties for the acidic soil conditions and blast disease tolerance and provides good seeds to local farmers in the village and province for better yields and quality. Mr. Hai Huu also tries and promotes the changes in cropping systems for better land use and family income in the area. He also motivates the contribution from his group members to build better local roads for children to get to school more conveniently.
Mr. Hai Chung has managed 3.2 ha of paddy land in the most intensive rice cropping area of Cho Gao District, Tien Giang province since 1954. He was an early experimenter with farming techniques and quickly adopted the IR8 rice variety in 1968. He raised pigs for meat and sale and used the manure on his rice land. He put ducks in the rice field at booting stage to fertilize the soil, aerate the water and control insects and weeds efficiently. With these achievements he was elected as Cooperative chairman of the village of An Phu, Cho Gao District, Tien Giang Province during the 1980s. Similarly, Mr. Tu Tai with 3 years-vocational training in agriculture began his agriculture activities in 1975. He has good contact to research institutions in the Mekong Delta to access technological information and to get new seed of pest resistant varieties for testing on his 0.8 ha rice field. He initially formed a group of 7 farmers in 1976-77 to multiply resistant rice varieties to supply to other farmers to stop the outbreak of Brown Plant Hopper in the village and district. He was then elected as Cooperative chairman of village of Than Cuu Nghia, Chau Thanh District (Tien Giang Province) during the $1980 \mathrm{~s}$. These men were the people who encouraged other farmers in their cooperatives to build local roads, electric pumping stations and irrigation systems. Farmers in their cooperatives but also in the whole communities benefited from their efforts. After that period, every home had electricity and could be reached by motorbikes instead of only by walking.

Mr. Hai Triem started his seed selection activities in village of Binh Hoa, Chau Thanh District (An Giang) in 1989 after visiting the demonstration field of rice yield trial in Cai Lay District, Tien Giang Province. He began to use part of his land ( 0.2 ha out of 1 ha) for the field trials. He also planted the panicle picking seeds in pots for preliminary observation. He has convinced his neighbors to form a seed production group for seed multiplication of the best selections from his field to supply good quality seeds to other farmers in his village and other places. He has learned breeding techniques and enriched his knowledge and skill in rice breeding and varietal selection from Can Tho 
University experts and provincial agricultural officers. Since 1995, he has been utilized by the Agricultural Extension Center to be the trainers for other farmers in several districts on seed production techniques. His mobilization by provincial agricultural extension as a trainer for farmers over the province is a special case. Other advanced farmers have only influenced farmers within their villages.

By the similar experience, Mr. Nam Chau (Tra Vinh), with 30 years farming experience on his 1.5 ha of paddy field, and Mr. Ba Chuong (Tien Giang), with more than 50 years farming experience on 1.0 ha rice field, are mobilized as local technicians and farmers' trainers in rice varietal selection and seed improvement for farmers' within their villages. They informally formed farmers groups and assigned each member to take care of one or some group activities for good quality seed production. They keep monitoring and coaching other farmers to do better jobs. Quality seeds are shared among group members and extra seeds are distributed to the farmers in other communities with the price just to cover the production cost. By their activities, farmers in their villages would have good seed available to produce every season. As a result, rice yield in their villages has been increasing year after year.

Since 1975 Mrs. Ly En with a primary school education has gained her experience and skill in agricultural production from training and her own work on her 1.2 ha of land of both paddy and upland crop fields in the village of Dai Tam, My Xuyen District, Soc Trang Province. She was elected as a local women leader since 1993. Her women agricultural extension club consists of 30 women farmers. She has convinced and led her group members to conduct trials on IPM, applying organic fertilizer, spraying bio-liquid fertilizer, field sanitation, using plastic cover in planting tomatoes, cucumbers, bitter gourds and other vegetables, the " 3 reductions and 3 gains" program in rice production (reductions of seed, pesticides and nitrogen fertilizer; gains in yield, grain quality and profit) and to reduce production cost and less depend on chemicals. She has received many certificates of appreciation as an advanced women farmer at the local, provincial and national level. Most notably, she got the National Reward from the Ministry of Agriculture and Rural Development in June 2002 as Creative Labourer in agriculture.

In 2003 there are thousands of such advanced farmers in each province and they have made great contributions to agriculture and rural development.

\section{Discussion}

\section{(1) Roles of advanced farmers}

In the early stage of economic development in most countries, when science and technology are not available or poorly developed, indigenous and local knowledge and experiences are very important to improve the agricultural productivity and resource use efficiency. Case studies show that advanced farmers in the Mekong Delta are not only good information providers but are also the first adventurers and inventors contributing to local technological development and diversification in agriculture. They are the key players in location-specific technology development. Mensvoort (1996) summarised the role of farmers confirming that Vietnamese farmers in the Mekong Delta have been particularly innovative in adjusting to the adverse conditions. Crawford et al. (2002) is confident that local knowledge, founded on farmers' activities in local conditions, is a key factor for maintaining a productive farming environment.

Advanced farmers are not only doing for their own benefit but also for the development of their communities. They have shared their knowledge and experience with their neighbors through daily contact, field coaching and training. Beyond technical matters, they also motivate and lead local people for community and rural development.

\section{(2) Characteristics of advanced farmers}

Knowledge and experience accumulation in farming are very important to become advanced farmers. Data from a 2003 survey showed that most advanced farmers are more than 50 years old $(74 \%)$ and the average age is 59 years old. The large majority of advanced farmers have more than 20 years experience 
in farming (79\%) with an average of 31 years of farming experience. This compares to research done by Thanh (2004) in 2001 that found farmers to be 47 years old with 27 years experience on average. Better educational background could help farmers access information easier and analyze them better to build up their advanced knowledge and skill. The average educational level of advanced farmers is secondary school, com- pared to primary school for average farmers (Table 2).

\section{(3) Attitudes of advanced farmers}

Attitudes or reasons for trying hard to become leading and advanced farmers in the area are (Table 3): 1) due to the real needs for better production and family income (100\% of respondents); (2) personal interest in trying new things (94.7\%); and, to help their relatives and neighbours $(78.9 \%)$. Some reasons are

Table 2. Characteristics of typical advanced farmers

\begin{tabular}{|c|c|c|c|c|}
\hline \multirow[t]{2}{*}{ Designation } & \multicolumn{2}{|c|}{ Advanced farmers (a) } & \multicolumn{2}{|c|}{ Average farmers (b) } \\
\hline & Frequency & $\%$ & Frequency & $\%$ \\
\hline Age & 19 & 100.0 & 430 & 100.0 \\
\hline Up to 30 & 0 & 0.0 & 26 & 6.0 \\
\hline $31-40$ & 0 & 0.0 & 101 & 23.5 \\
\hline $41-50$ & 5 & 26.3 & 163 & 37.9 \\
\hline Above 50 years old & 14 & 73.7 & 140 & 32.6 \\
\hline Mean & \multicolumn{2}{|c|}{$58.6 \pm 12.5$} & \multicolumn{2}{|c|}{$47.2 \pm 12.0$} \\
\hline Years of farming experience & 19 & 100.0 & 430 & 100.0 \\
\hline Up to 10 & 0 & 0.0 & 34 & 7.9 \\
\hline $11-20$ & 4 & 21.1 & 100 & 23.3 \\
\hline $21-30$ & 8 & 42.1 & 164 & 38.1 \\
\hline$>30$ years & 7 & 36.8 & 132 & 30.7 \\
\hline Mean & \multicolumn{2}{|c|}{$31.5 \pm 12.6$} & \multicolumn{2}{|c|}{$26.8 \pm 12.1$} \\
\hline Educational level & 19 & 100.0 & & \\
\hline Primary school (1-5) & 9 & 47.4 & & \\
\hline Secondary school (6-9) & 1 & 5.3 & & \\
\hline High school (10-12) & 6 & 31.6 & & \\
\hline University & 3 & 15.8 & & \\
\hline In average & \multicolumn{2}{|c|}{ 6-9 (Secondary school) } & \multicolumn{2}{|c|}{ 1-5 (Primary school) } \\
\hline
\end{tabular}

Notes: (a) Data from a personal interview of 19 representative advanced farmers in different agro-ecosystems: flooded, irrigated and rainfed saline areas, in November-December 2003 by the author. (Data was rearranged to be compatible with Thanh (2004) data.

(b) Data from a survey of 430 randomly selected farmers in 4 selected provinces of Soc Trang, Bac Lieu, Tra Vinh and Ben Tre, in 2001 (Thanh, 2004)

Table 3. Reasons (emotion) for trying to be advanced farmers

\begin{tabular}{lc}
\hline \hline Reasons & Frequency (\%) \\
\hline There is need for better performance and family income & 100.0 \\
Personal interest to try something new & 94.7 \\
To help his relatives and neighbours & 78.9 \\
Encouragement from scientists and local extensionists & 42.1 \\
For social recognition & 31.6
\end{tabular}

Source: Field data from personal interview of 19 representative advanced farmers in different agro-ecosystems: flooded (4), irrigated (9) and rainfed saline (6), in November-December 2003 by the author. 
due to social recognition and willingness to serve their communities (31.6\%). They are happy and feel proud when others appreciate their works and sometimes because the researchers and extension workers encourage them to do (42.1\%). These results imply that the economic reason is the most important motivation for trying to be more technically advanced in farming. They first think of improving their family income and living standard. Personal character and attitude is also important because many farmers are under the same conditions but only a few of them become advanced. No difference in attitudes for being advanced farmers was found from different agroecosystems.

\section{(4) Agricultural development issues}

Based on the trends in agricultural development from developed countries, the developing countries tend to move from subsistence agriculture to not only modernized but also sustainable agriculture. By including sustainable agriculture practices that avoid environmental destruction, developing countries intend to meet the needs of the present generation without compromising the ability of future generations to meet their needs (Keiner, 2004). Vietnam is in this transition stage but it has to create a unique pattern of agricultural development due to a different resource endowment, a technological backlog, and opportunity and socio-political structure from other developing countries in the region.

To speed up the rural development process in the Mekong Delta, technological promotion alone is not enough. There is a need for better links and coordination between several groups including: (1) policy advocates, including infrastructure, finance and market, by local authorities; (2) organizational and management efforts by people's organizations such as farmer's associations, women's unions, and youth unions; and (3) technology component by research institutions and extension network. In our viewpoint, all efforts for agriculture and rural development should be linked and well coordinated and should go through advanced farmers for better performance and high efficiency

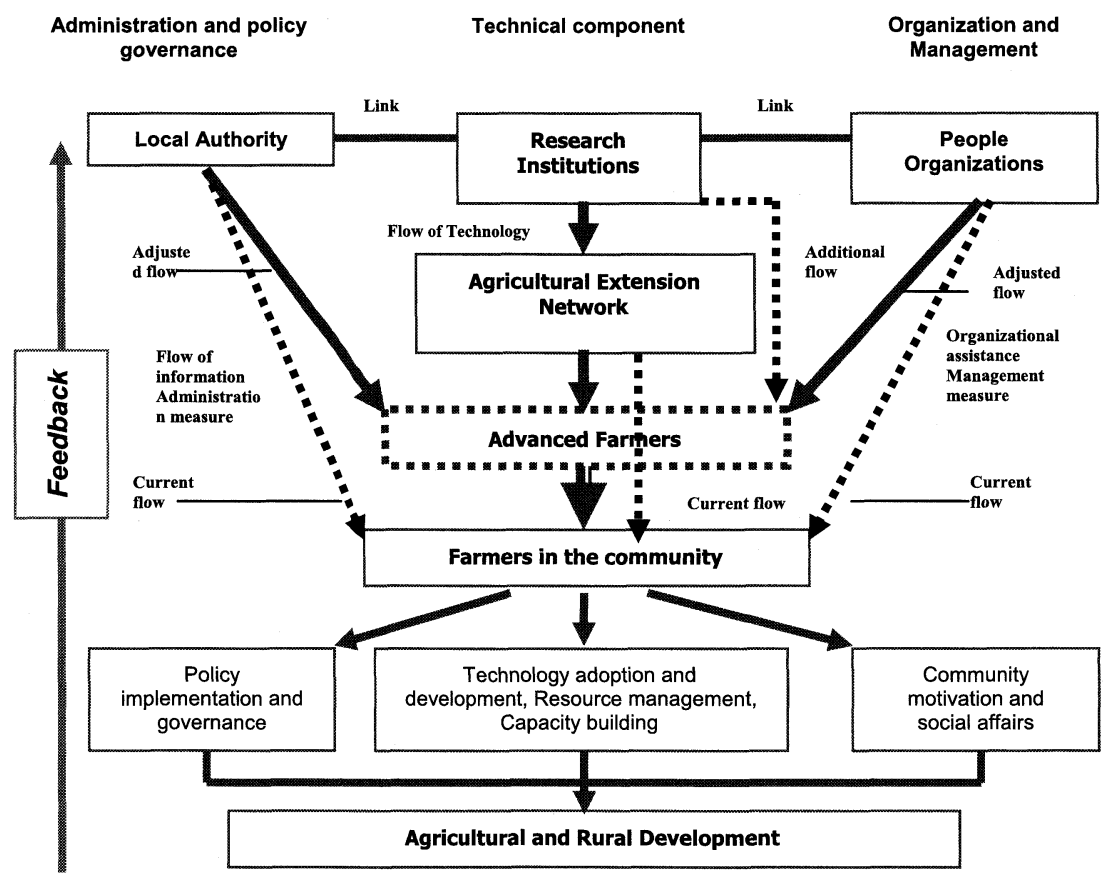

Figure 2. Summary diagram on the role of Advances farmers in the community Arrows show flows of information, knowledge, materials, and technologies. 
both at upper level delivering bodies (government, research, extension and people organizations) and lower receiving ones (advanced farmers and rural farming communities). This approach can strongly support and facilitate the advanced farmers to perform their leading roles better at the grass roots level.

The adjusted framework and the role of advanced farmers can be summarized in Figure 2 .

In the local community, advanced farmers play the key role as informal leadership in all activities for agriculture and rural development. Advanced farmers are active and more open to interact with the supporting, services and even political systems. Through that channel, flows of information, knowledge, technologies, and materials will be disseminated to other farmers in the whole community. Advanced farmers could be the pioneer to try, to modify when necessary, to apply and disseminate the knowledge, technologies through training, coaching and motivate people to follow. Advanced farmers also take a leading role in social affairs to build up better life for the community. In the whole process, advanced farmers contribute to capacity building, resource management and community development.

Wherever, the advanced farmers are identified and supported in appropriate ways, the program implementation would be successful.

\section{Concluding remarks}

Under different agro-ecological conditions, farmers in the Mekong Delta have, through learning by doing, developed various technologies in soil, water and crop management to overcome problems and constraints of their lands for better agricultural production. Vietnamese farmers in the Mekong Delta deal reasonably with the difficulties in the utilization of the land for agriculture.

Their knowledge is built not only from their own experience, but also from interaction with other people. This practical knowledge is very valuable and should be make available to agricultural and rural development processes.
Advanced farmers play an important role not only in technological contributions but also in community development activities at local level. They are the bridges between scientists, extensionists, local authorities and farming communities. Moreover, many references proved that information supplied by neighbouring farmers is often seen as more important and reliable than those provided by outsiders. However, their roles had been neglected during the collectivization period and under-utilized under the renovation period. Therefore, the agricultural extension network today should consider the advanced farmers as active partners and involve them as local motivators for successful agriculture and rural development programs.

To better facilitate and enhance the roles of advanced farmers, more education, training and incentive policies are needed to encourage their active and effective performance. In addition, better group (in the form of production groups, extension clubs or cooperatives) formation and management can facilitate advanced farmers' role for faster and more effective agriculture and rural development process.

\section{Acknowledgment}

We would like to express our sincere thank to the two referees of the Journal of Rural Problem, The Association for Regional Agricultural and Forestry Economics for their valuable comments to make this paper much better. Our deep appreciation goes to Dr. Douglas H. Constance, Associate Professor, Department of Sociology, Sam Houston State University (USA) for his kindness in checking scientific English writing style as native English speaker. Special thank is due to our advanced farmers in the Mekong Delta who have been cooperating and supporting to make this research possible.

\section{Notes}

1) A socio-political body of farmers' representatives with network from central to village levels

2) A group of farmers formed for technical exchange and dissemination at community level

3) A technical assistant agent in agriculture at community 
level

4) FFS: a training method of learning by doing using actual farmer's fields

5) FPR: a kind of simplified research done by farmers for local adaptation of new varieties or technologies

6) DANIDA: Danish International Development Assistance

7) CBDC: An International program for Community Biodiversity Development and Conservation

8) PPB/PVS: An approach in plant breeding with farmers' participation at different levels and degrees

\section{References}

[1] Abedin, Z.M., T. Paris and N.N. De (2004). Farmer perceptions of impact of rice intensification and row seeder on rural livelihoods in South Vietnam. Paper presented at the International Flood-prone rice ecosystems final conference. Can Tho University, Vietnam, 5-7 Feb. 2004.

[2] Cho, K. (2001). New Agricultural Cooperatives in Vietnam-Discussions based on the Japanese Experience. In: Cho K. and Yagi H. (editors) Vietnamese Agriculture under Market-oriented Economy. The Agricultural Publishing House, Hanoi, Vietnam, 2001. pp. 281-318.

[3] Crawford, H.K., R.B. Murray-Prior and H. Jenkins (2002) Using farmer 'local knowledge' to best advantage. Paper presented at the International Sociology Association Conference, Australia, July 2002.

[4] De, N.N. (1996) Seed supply and participatory plant breeding in the Mekong Delta of Vietnam. Paper presented at the International NGO Conference, Leipzig, Germany, 14-16 June 1996.

[5] Hayami, Y. (1975). A Century of Agricultural Growth in Japan: Its Relevance to Asian Development. University of Tokyo Press. pp. 44-83, 195-215.

[6] IRRI (1985). Insights of outstanding farmers. IRRI, Manila, Philippines. pp. 60-65.

[7] Keiner, M. (2004). Re-Emphasizing Sustainable Development-The Concept of "Evolutionability" on living chances, equity, and good heritage. Environment, Development and Sustainability 6: 379-392, 2004. Kluwer Academic Publishers.

[8] Mensvoort, M.E.F. (1996). Soil knowledge for farmers, farmer knowledge for soil scientists: The case of acid sulphate soils in the Mekong Delta, Vietnam. Ph.D Thesis at Wageningen Agricultural University.

[9] Nga, T.T., D.V. Ni and V.T. Xuan (1996). Cultivation of sugarcane on acid sulphate soils in the Mekong Delta. In: D.L. Dent and M.E.F. van Mensvoort (editors) Selected papers of the Ho Chi Minh symposium on acid sulphate soils. ILRI Publication 53, ILRI, Wageningen, the Netherlands, pp. 123-128.

〔10〕 Pingali, P.L. and V.T. Xuan (1990) Vietnam: Decollectivization and rice productivity growth. IRRI Social Science Division papers, No. 89-16.

[11] Subedi, A. et al. (2001). Who maintains crop genetic diversity and How: Implications for On-farm conservation and Utilization. Paper presented at the International symposium on Managing Biodiversity in agricultural ecosystems organized by the United Nations University, International Plant Genetic Resources Institute and the Secretariat of the Convention on Biological Diversity, Montreal, Canada, 8-10 November 2001.

〔12] Thanh, D.N. (2004). Comparative Socio-economic Analysis of Selected Farming Systems in the Coastal Areas of the Mekong Delta. In: R. Yamada (editor) The Development of Agriculture and Sustainable Farming Systems in the Mekong Delta. Tre Publishing House. JIRCAS-Can Tho University, pp. 149-187.

〔13] Tri, L.Q. (1996). Developing management packages for acid sulphate soils based on farmer and expert knowledge: Field study in the Mekong Delta, Vietnam. Ph.D Thesis at Wageningen Agricultural University.

〔14〕 Xuan, V.T., N.K. Quang and L.Q. Tri (1982). Rice cultivation on acid sulphate soils in the Vietnamese Mekong Delta”. In H. Dost and N. van Breemen, eds., Proceedings of the Bangkok symposium on acid sulphate soils. ILRI Publication 31, ILRI, Wageningen, the Netherlands, pp. 251-259.

[15] Xuan, V.T., N.V. Sanh, D.V. Ni, V.T. Anh and P.T. Dung (1991). Studies on zero tillage technique for rice cultivation on well-developed acid sulphate soils in the Mekong Delta”. In van Mensvoort ed., EEC Vietrep 004, Report of activities, Department of Soil Science and GeologyWageningen Agricultural University.

[16] Xuan, V.T. and N.N. De (1993). Present status of Agricultural Extension in Vietnam. Paper presented at the first Southeast Asia workshop on formulation of project proposals on technology transfer for major food crop production, FAO and UAF, Ho Chi Minh City, 6-9 Dec. 1993.

[17] Xuan, V.T. (1997). Twenty-first century's vision on the Mekong Delta development.

（受理日：2005 年 4 月 4 日） 